\title{
A proteolytic fragment from the central region of $p 53$ has marked sequence-specific DNA-binding activity when generated from wild-type but not from oncogenic mutant p53 protein
}

\author{
Jill Bargonetti, ${ }^{1}$ James J. Manfredi, ${ }^{1}$ Xinbin Chen, ${ }^{1}$ Daniel R. Marshak, ${ }^{2}$ and Carol Prives ${ }^{1}$ \\ ${ }^{1}$ Department of Biological Sciences, Columbia University, New York, New York 10027 USA; ${ }^{2}$ Cold Spring Harbor \\ Laboratory, Cold Spring Harbor, New York 11724 USA
}

p53 is a sequence-specific DNA-binding oligomeric protein that can activate transcription from promoters bearing p53-binding sites. Whereas the activation region of p53 has been identified within the amino terminus, the location of the specific DNA-binding domain has not been reported. Thermolysin treatment of p53 protein generates a stable protease-resistant fragment that binds with marked specificity to p53 DNA-binding sites. Amino-terminal sequencing of the fragment located the thermolysin cleavage site to residue 91. Because the fragment does not contain the cdc2 phosphorylation site at Ser-315, we conclude that the the site-specific DNA-binding domain of p53 spans the central region of the protein. The vast majority of the mutations in oncogenically derived p53 proteins are located within this central portion of the molecule. Such mutant p53 proteins exhibit defective sequence-specific DNA-binding. Although thermolysin digestion of mutant p53 proteins generates proteolytic patterns that differ from wild-type protein, one mutant tested, His-273, generates a resistant fragment that migrates with a similar electrophoretic mobility to the wild-type protease-resistant fragment. Interestingly, although intact mutant His-273 protein binds to DNA at $20^{\circ} \mathrm{C}$, the thermolysin-resistant mutant fragment does not. In addition, the central protease-resistant, site-specific binding region of wild-type p53 does not demonstrate nonspecific DNA-binding. Thus, although sequences outside of the central region of p53 contribute to both nonspecific DNA-binding and oligomerization, they are not required for sequence-specific DNA-binding.

[Key Words: p53; DNA-binding domain; sequence-specific DNA binding]

Received August 16, 1993; revised version accepted September 30, 1993.

The p53 gene encodes a protein that can function to suppress progression through the cell cycle in response to DNA damage (for review, see Hartwell 1992; Lane 1992; Prives and Manfredi 1993). Mutations in p53 can cause cells to become oncogenically transformed (for review, see Lane and Benchimol 1990; Levine et al. 1991). The normal function of $\mathrm{p} 53$ is regulated, at least in part, by the ability of the protein to bind site specifically to DNA (for review, see Vogelstein and Kinzler 1992). Mutation of the p53 gene is frequently found in many forms of human cancer (Nigro et al. 1989; for review, see Hollstein et al. 1991), and the tumor-derived mutant p53 proteins that have been tested thus far do not bind specifically to DNA in vitro (Bargonetti et. al. 1991; Kern et al. 1991a). Wild-type p53 binds nonspecifically to DNA (Steinmeyer and Deppert 1988; Kern et al. 1991b), as well as specifically to diverse DNA sequences that contain forms of the consensus sequence $5^{\prime}-\mathrm{Pu} \mathrm{Pu} \mathrm{Pu} \mathrm{C} \mathrm{(A/T)}$ (T/A) G Py Py Py-3' (El-Deiry et al. 1992; Funk et al.
1992). Wild-type, but not mutant, p53 can activate transcription from constructs containing strong p53-binding sites both in vitro (Farmer et al. 1992) and in vivo (Funk et al. 1992; Kastan et al. 1992; Kern et al. 1992; Scharer and Iggo 1992; Zambetti et al. 1992). Therefore, there is a strong connection between p53 DNA binding and normal p53 function.

The p53 protein, which is phosphorylated at residues within the amino- and carboxy-terminal regions, is composed of three separate structural regions: an acidic proline-rich amino terminus that mediates transcriptional activation (Fields and Jang 1990; Raycroft et al. 1990; Unger et al. 1992), a hydrophobic internal region, and a region within the carboxyl terminus that contains an oligomerization domain (Shaulian et al. 1992; Sturzbecher et al. 1992; Pavletich et al., this issue). Present in the central portion of the protein are four regions that are evolutionarily conserved within all vertebrate species examined (Soussi et al. 1990). Additionally, 
approaches using antibodies have suggested that the central region contains determinants that regulate the conformation of p53 (Hinds et al. 1987; Cook and Milner 1990; Gannon et al. 1990). To date, the specific DNAbinding domain of $\mathrm{p} 53$ has not been identified. The mutant $\mathrm{p} 53$ proteins found in human cancer contain amino acid substitutions or deletions that fall within the central portion of p53 and tend to cluster within the four conserved regions (for review, see Hollstein et al. 1991). This, coupled with the fact that oncogenically derived mutant $\mathrm{p} 53$ proteins do not bind to DNA, suggests that the central domain of p53 may be important for DNAbinding activity. Additionally, SV40 large $\mathrm{T}$ antigen binds to the central region of p53 (Tan et al. 1986; Jenkins et al. 1988; Ruppert and Stillman 1993) and, as such, inhibits the in vitro DNA-binding ability of the wildtype protein (Bargonetti et al. 1992).

Because the DNA-binding property of p53 is central to the function of the protein, it is important to determine what region of the protein contains the sequence-specific DNA-binding domain. Because distinct domains of proteins are frequently resistant to broad-range proteases (Heinrikson 1977), we examined the binding of p53 proteolytic fragments to oligonucleotides containing strong p53-binding sites. Using thermolysin digestion as a means to generate p53 fragments we have found that a stable p53 proteolytic fragment, $\sim 27 \mathrm{kD}$ in mass, maintains marked sequence specificity for DNA binding. In addition, we have compared the protease cleavage products generated from mutants with those seen with wildtype $\mathrm{p} 53$. In some cases, the fragments generated were very similar to wild type, whereas in others they were different. In addition to determining the site-specific DNA-binding domain of $\mathrm{p} 53$, our data address the variability between different oncogenically derived mutant forms of $\mathrm{p} 53$.

\section{Results}

Proteolysis of human p53 yields a sequence-specific DNA-binding fragment

To define the region of $\mathrm{p} 53$ that binds to DNA, we tested the ability of a broad range protease, thermolysin, to generate protein fragments capable of binding a strong p53 DNA-binding sequence using the electrophoretic mobility shift assay (EMSA). Immunopurified wild-type human p53 was treated with increasing quantities of the enzyme under DNA-binding conditions; subsequently, oligonucleotides containing the strong p53-binding site from the murine muscle creatine kinase promoter (MCK), identified by Zambetti et al. (1992), were added to each reaction mixture. These samples contained a sufficient amount of protein to be analyzed by SDS-PAGE to identify the p53 proteolytic fragments (Fig. 1A); aliquots were then examined by EMSA to determine whether any of the proteolytic fragments could bind to DNA (Fig. 1B). The proteolytic fragments detected after digestion demonstrated that the higher levels of thermolysin generated a single resistant p53 fragment mi-
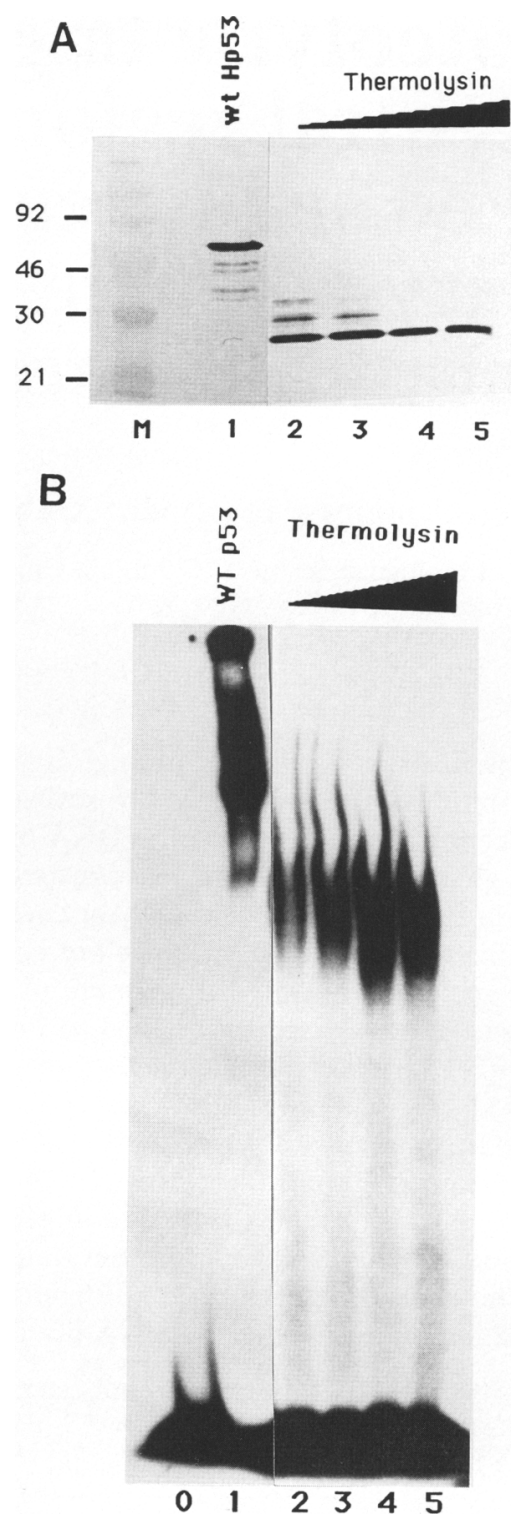

Figure 1. Proteolysis of human p53 yields a fragment that binds DNA. Human p53 $(7 \mu \mathrm{g})$ was digested with increasing amounts of thermolysin at $37^{\circ} \mathrm{C}$ for $15 \mathrm{~min}$ such that the ratios (wt/wt) of protease/p53 were 1:7, 1:3.5, 1:2.3, and 1:1.75 (lanes 2-5, respectively). ${ }^{32} \mathrm{P}$-Labeled MCK oligonucleotide ( 1.5 pmole) was added to each reaction, and incubation was continued at $20^{\circ} \mathrm{C}$ for $30 \mathrm{~min}$. Aliquots of the reaction mixtures were then analyzed for p53 proteolytic digestion patterns $(A)$ and DNAprotein complexes $(B)$. $(A)$ Proteolyzed products were resolved on a $10 \%$ polyacrylamide gel followed by electrotransfer to nitrocellulose and probing with pAb 240. (Lane 1) Untreated p53; (lane $M$ ) prestained standards (molecular mass in $\mathrm{kD}$ at left). $(B)$ EMSA of the proteolysis product reaction mixtures on a $4 \%$ native gel. (Lanes 1-5) The same protease reaction mixtures show in $A$; (lane 0 ) no p53 protein.

grating at $\sim 27 \mathrm{kD}$ by comparison with standard prestained polypeptides (Fig. 1A, lanes 4,5). Although the detection of these fragments was by Western blot anal- 
ysis with the p53-specific antibody pAb 240, silver staining of gels containing such digests showed similar products in this size range (e.g., see Figs. $4 \mathrm{~B}$ and $6 \mathrm{~A}$ ). The EMSA of aliquots of these proteolysis reaction mixtures showed that the thermolysin-digested protein bound well to the oligonucleotide, demonstrating an affinity that was in the range of full length p53 (Fig. 1B, lanes $2-5$ ). It is interesting to note that the binding ability of the thermolysin treated protein increased with the higher levels of protease used. This was commensurate with the disappearance of larger detectable p53 fragments (cf. Fig. 1, A and B, lanes 2-5), and the appearance of smaller fragments (data not shown), suggesting the possibility that such fragments either mask or inhibit the DNA-binding ability of the major protease-resistant product.

To further analyze the DNA-binding properties of the thermolysin-resistant fragment of p53 we examined its ability to bind to another strong DNA site for p53 from the human ribosomal gene cluster (RGC) identified by Kern et al. (1991). Previously, we have shown that p53 binds with similar affinity to MCK and RGC (Bargonetti et al. 1992). In this experiment wild-type (RGC-W) and mutant (RGC-M) oligonucleotides were incubated with either full-length or thermolysin-treated p53 in the presence of increasing amounts of competitor DNA poly[d(IC)l; Fig. 2). EMSA analysis demonstrated that under the conditions of the binding assay, although full-length p53 binding to RGC-W was clearly stronger, the protein was also capable of binding to RGC-M (Fig. 2, cf. lanes 9-11 with lanes 2-4). In contrast, the thermolysin-digested p53, which demonstrated strong binding to RGC-W, displayed virtually no detectable binding to RGC-M (Fig. 2, cf. lanes 12-14 with lanes 5-7). PhosphorImaging of the shifted DNA species showed that in the absence of competitor DNA the thermolysin-resistant fragment bound to RGC-W $50 \%$ as efficiently as full-length protein (Fig. 2, cf. lanes 9 and 12). At the highest level of competitor DNA, full-length p53 bound to RGC-M $27 \%$ as efficiently as RGC-W (Fig.2, cf. lanes 4 and 11), whereas the p53 fragment bound RGC-M only $1 \%$ as efficiently as RGC-W (Fig. 2, cf. lanes 7 and 14).The binding displayed by full-length p53 to RGC-M may be controlled by sequences outside the central-core, thermolysin-resistant fragment. These findings indicate that the thermolysinresistant $\mathrm{p} 53$ fragment displays strong sequence-specific DNA-binding activity and displays little nonspecific DNA-binding activity as compared with the full-length, wild-type protein. This suggests that when excised from the intact protein, the central region of $\mathrm{p} 53$ has lost some of the determinants that stabilize DNA-binding.

\section{The $\sim 27-k D$ thermolysin-resistant DNA-binding fragment spans the central region of $p 53$}

The proteolytic p53 fragments shown in Figure 1 were detected by immunostaining with pAb 240 . The epitope of pAb 240 has been mapped to residues 212-217 (Stephan and Lane 1992), suggesting that this region of p53 is contained within the DNA-binding portion. This

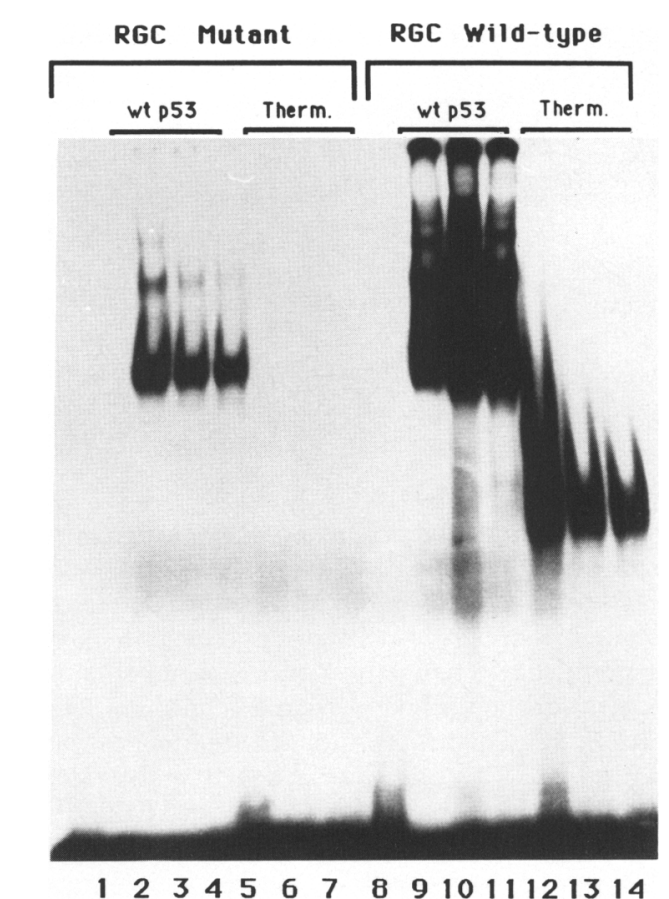

Figure 2. The thermolysin-resistant p53 fragment binds sequence specifically to DNA. Untreated p53 (3.5 $\mu$ g; lanes 2-4 and 9-11) or $\mathrm{p} 53$ treated at $37^{\circ} \mathrm{C}$ for $30 \mathrm{~min}$ with thermolysin [1:1.75 wt/wt; lanes 5-7 and 12-14] were incubated with $25 \mathrm{ng}$ of either RGC-M (lanes 2-7) or RGC-W (lanes 9-14) ${ }^{32} \mathrm{P}$ labeled oligonucleotides in the presence of no competitor (lanes $2,5,9,12)$, or $150 \mathrm{ng}$ (lanes $3,6,10,13$ ) or $300 \mathrm{ng}$ (lanes $4,7,11,14$ ) of poly $[\mathrm{d}(\mathrm{I}-\mathrm{C})]$. Lanes 1 and 8 contain no p53 protein.

is consistent with additional immunochemical data from Western blot analysis, which showed that the $\sim 27$ $\mathrm{kD}$ thermolysin-resistant $\mathrm{p} 53$ product lacks both the pAb 1801 epitope between 32 and 79 (Banks et al. 1986) at the amino terminus, and the pAb 421 epitope between residues 371 and 381 at the carboxyl terminus (WadeEvans and Jenkins 1985); data not shown). Before obtaining further information about the sequence of the stable proteolytic p 53 fragment, it was necessary to determine whether it was actually bound to DNA. This was accomplished by isolating DNA-protein complexes containing either full-length or proteolyzed p53 from acrylamide gels, eluting the protein from such complexes, and analyzing the eluted protein by SDS-PAGE (Fig. 3A). Because the only polypeptide detectable in the thermolysin-treated p53-DNA complex migrated as a fragment within the size range of $27-29 \mathrm{kD}$, the likelihood that this fragment contained the site-specific DNA-binding domain of $\mathrm{p} 53$ was high (for discussion of the size of the p53 fragment, see below). Accordingly, a larger preparation of the the thermolysin-resistant product was generated, electrophoresed on an SDS-polyacrylamide gel, electroblotted onto a polyvinylidene diflouride (PVDF) membrane, stained with Coomassie blue, and then amino-terminally sequenced by gas-phase analysis. The 

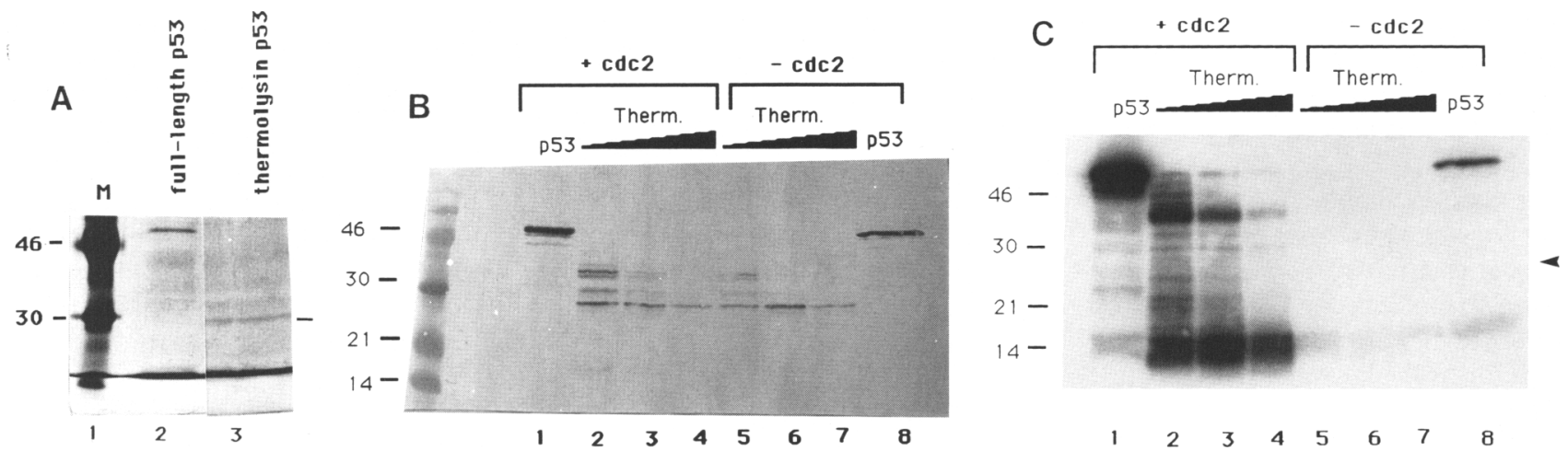

Figure 3. The $\sim 27-\mathrm{kD}$ thermolysin-resistant fragment spans the central region of p53. $(A)$ Intact or thermolysin-treated p53 proteins were bound to ${ }^{32} \mathrm{P}$-labeled MCK oligonucleotide and DNA-protein complexes were resolved on a $4 \%$ native polyacrylamide gel. ${ }^{32} \mathrm{P}$-labeled bands corresponding to the shifted species (identified by wet autoradiography) were excised from the gel, and the protein was eluted. Shown here is a silver-stained $10 \%$ SDS-polyacrylamide gel with the eluted polypeptides from the untreated-(lane 2$)$ and the thermolysin-digested- (lane 3) p53. Lane 1 contains markers for size. (B) p53 protein was incubated for 30 min with [ $\left.\gamma^{32} \mathrm{P}\right] \mathrm{ATP}$ and other reagents as described in Material and methods with (lanes 1-4) or without (lanes 5-8) cdc2 kinase before incubation with thermolysin. Subsequent thermolysin treatment of p53 was at a ratio of 1:1.75 for 30 min (lanes 2,5), 45 min (lanes 3,6 ), or 60 min (lanes 4,7$)$ at $37^{\circ} \mathrm{C}$. Samples were analyzed by $15 \%$ SDS-PAGE, followed by electrotransfer to nitrocellulose and were probed with pAb 240 . (C) autoradiograph of the blot described in $B$. The arrowhead marks the position of the $\sim 27-\mathrm{kD}$ thermolysin-resistant fragment detected in lanes $2-7$ of $B$.

sequence of the polypeptide LSSSVPSQKT identified the thermolysin cleavage site to be at amino acid 91.

To gain information about the carboxyl terminus of the protease-resistant fragment, we took advantage of the single cdc2 kinase site on human p53 at Ser-315 (Bischoff et al. 1990). The full-length p53 was treated with purified $c d c 2$ kinase and $\left[\gamma^{-32} \mathrm{P}\right] \mathrm{ATP}$, and the labeled protein was digested with thermolysin to generate the resistant fragment. After SDS-PAGE, electrotransfer to nitrocellulose, and Western blotting with pAb 240 (Fig. 3B), the blot was exposed to X-ray film to ascertain the location of the radioactive phosphate (Fig. $3 \mathrm{C}$ ). The p53 preparation, when incubated alone with $\left[\gamma^{-32} \mathrm{P}\right] \mathrm{ATP}$, displayed a small amount of endogenous-associated protein kinase activity (Fig. 3C, lane 8). However, upon treatment with cdc2 kinase, the protein incorporated significantly more label (Fig. 3C, lane 1). The highest level of thermolysin digestion, where the only species detected by Western blot analysis was the $\sim 27-\mathrm{kD}$ fragment, also revealed a $\sim 14-\mathrm{kD}$ species by autoradiography that was strongly labeled with $\gamma-{ }^{32} \mathrm{P}$ and several additional minor labeled species (Fig. 3C, lanes 2-4). PhoshorImaging showed that the minor labeled species were relatively insignificant when compared with the full-length protein. Whereas the autoradiograph showed that the labeled species in the vicinity of the position of the $\sim 27-\mathrm{kD}$ polypeptide contained far less radioactivity than had been incorporated into full-length p53 (Fig. 3, cf. $B$ and $C$, the Western blot demonstrated that an abundant quantity of the $\sim 27-\mathrm{kD}$ thermolysin-resistant fragment had been generated (Fig. 3B, lanes 2-7). We therefore conclude that the $\mathrm{p} 53$ thermolysin-resistant fragment does not contain the Ser-315 site that was phosphorylated by cdc2 kinase. Additionally, because human p53 contains a potential thermolysin cleavage site between Asn-306 and Leu-307, it is likely that Asn306 is the carboxy-terminal amino acid of the DNAbinding fragment. The endogenously labeled p53 also yielded the $\sim 14-\mathrm{kD} \gamma^{-32} \mathrm{P}$ labeled material (Fig. 3C, lanes 5-7) suggesting that the endogenous kinase phosphorylates the protein at the carboxyl terminus. This is consistent with the fact that Herrman et al. (1991) have identified a casein kinase II activity associated with p53, and that casein kinase II was shown by Meek et al. (1990) to phosphorylate a single site at Ser-389.

Taken together, our data with antibodies, amino-terminal sequencing, cdc2 kinase treatment, and relative SDS-PAGE migration show that the DNA-binding domain of p53 is located within a protease-resistant fragment of p53 that extends from amino acid 91 to approximately amino acid 306 . Thus, the specific DNA-binding domain resides within the central conserved portion of the protein. We first determined that the thermolysinresistant p53 fragment has a molecular mass close to that of $27 \mathrm{kD}$ by comparison with prestained markers, particularly with the $29-\mathrm{kD}$ carbonic anhydrase marker polypeptide. However, in cases where the same digests were analyzed on gels containing unstained markers (such as that shown in Fig. 3A), the apparent migration of the single stable thermolysin-generated p 53 fragment was somewhat closer to that of the $30-\mathrm{kD}$ marker polypeptide, indicating a somewhat greater molecular mass of $\sim 28 \mathrm{kD}$. Examination of the two kinds of standards run in adjacent wells on polyacrylamide gels showed that prestained markers migrate more slowly than their unstained counterparts, possibly because of the added mass of the dyes, thus explaining possible discrepancies between different experiments. Nevertheless, because the thermolysin-resistant fragment extends from residue 91 at the amino terminus to, at the uppermost, residue 
306 at the carboxyl terminus, thus containing a maximum of 205 amino acids, this would correspond to a polypeptide with an actual molecular mass in the vicinity of $23-24 \mathrm{kD}$, rather than the estimated molecular mass of $27-28 \mathrm{kD}$ that was derived from electrophoretic mobility. This discrepancy may be related to the fact that intact p53 itself, whose migration on gels would suggest that it has a molecular mass of $\sim 53 \mathrm{kD}$, has an actual molecular mass of $\sim 44 \mathrm{kD}$.

\section{Proteolysis of mutant p53 proteins demonstrates variability in cleavage patterns}

We have constructed recombinant baculoviruses that express tumor-derived mutant p53 proteins Ala-143, Trp248, His-273, and His-175, with amino acid substitutions that are each located within a different conserved region. When assayed by DNase I footprinting, these mutant proteins did not exhibit site-specific DNA-binding ability (Bargonetti et al. 1992). It was therefore of interest to examine whether differences in the thermolysin cleavage patterns of the mutant proteins could be discerned. Partial digestion of the immunopurified p53 proteins revealed that both the His-273 and Trp-248 mutant proteins have proteolytic patterns similar (but not identical) to wild-type protein (Fig. 4A, lanes 1-9). These two mutant proteins show additional similarity to wild-type p53 in that more extensive proteolysis by thermolysin generates a stable fragment that also migrates at $\sim 27 \mathrm{kD}$ in SDS-PAGE (Fig 4B, lanes 7-12). Partial proteolysis of the His-175 mutant p53 (Fig. 4A, lanes 10-12) demonstrated a proteolytic pattern substantially different from that of the wild-type protein; and after more extensive treatment virtually no His-175 p53 proteolytic fragments remained (Fig. 4B, lanes 13-15). The Ala-143 mutant protein also appeared to be consistently more sen- sitive to proteolysis; therefore, it was not possible to determine whether this mutant generated a partial pattern similar to or different from that of wild type (data not shown). However, it was clear that as with His-175 p53, Ala-143 p53 did not yield a stable thermolysin-resistant fragment (Fig. 4B, lanes 4-6). These data, obtained with thermolysin treatment of mutant proteins, suggest that His- 273 and Trp- 248 mutant p53 proteins maintain a structure similar to wild-type while Ala-143 and His-175 mutant p53 proteins do not.

\section{The thermolysin product of His-273 mutant p53 does not bind to DNA}

When we showed previously that the immunopurified mutant p53 proteins described above do not display sequence-specific DNA-binding activity, the conditions used for those experiments included incubation of proteins and DNA at $37^{\circ} \mathrm{C}$. However, more recently we have found that some mutant p53 proteins bind to DNA at lower temperatures (Friedlander et al., unpubl.). The DNA-binding ability of one of these mutants, His-273, was compared with wild-type p 53 by EMSA in both the absence and presence of competitor DNA at $20^{\circ} \mathrm{C}$ (Fig. 5). The wild-type and mutant p53 proteins displayed similar over-all binding when no competitor DNA was present (Fig. 5, cf. lanes 2 and 7). It should be noted that differences in the wild-type and mutant p53 oligomeric forms associated with DNA were observed frequently. However, when unlabeled competitor DNA was added there was a marked difference between the binding ability of the two proteins. As expected, wild-type $\mathrm{p} 53$ binding was strongly competed by the specific oligonucleotide RGC-W and very poorly competed by the mutant RGC-M (Fig. 5, lanes 8-11). In contrast, in the case of His-273, the unlabeled mutant oligonucleotide RGC-M
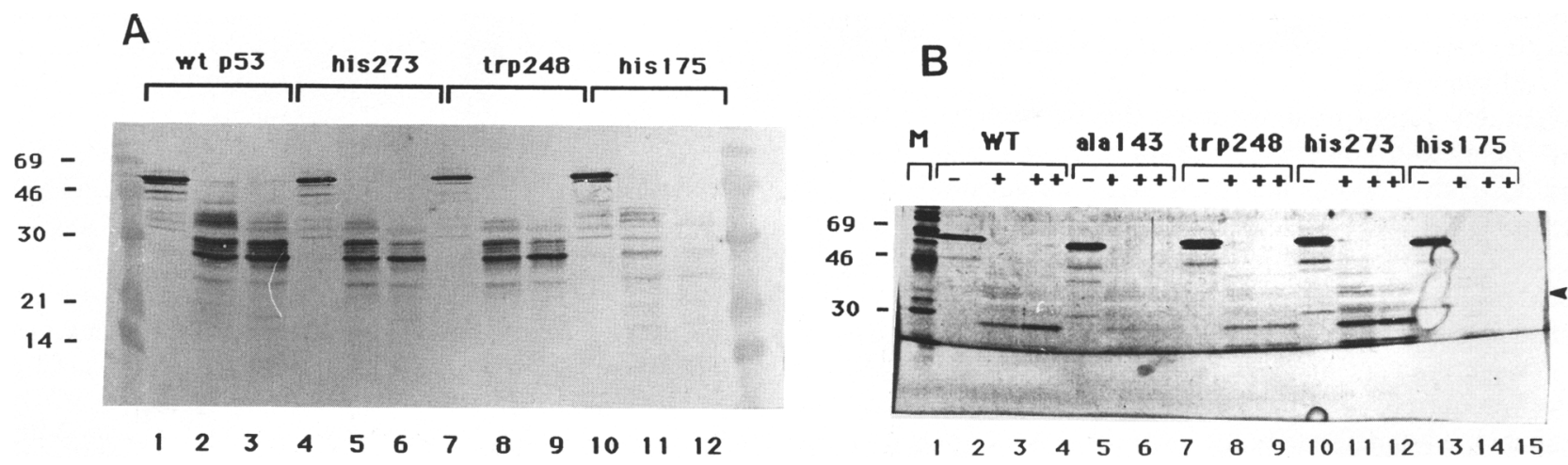

Figure 4. Proteolysis of mutant p53 proteins demonstrates variability in the cleavage patterns. $(A)$ Limited digestion of wild-type and mutant p53 proteins. Wild-type human p53 (lane 1), His-273 (lane 4), Trp-248 (lane 7), and His-175 (lane 10) proteins (3 $\mu$ g) were digested with thermolysin at a protease to p53 ratio (wt/wt) of 1:0.4 (lanes 2,5,8,11) or 1: 0.2 (lanes $3,6,9,12$ ), respectively, for 30 min at $20^{\circ} \mathrm{C}$. Samples were analyzed by $15 \%$ SDS-PAGE, followed by electrotransfer and immunoblotting with pAb240. $(B)$ Extensive proteolysis of mutant p53 protein. Approximately $1 \mu \mathrm{g}$ of wild-type human p53 (lane 1), Ala-143 (lane 4), Trp-248 (lane 7), His-273 (lane 10 ), and His-175 (lane 13) was digested with thermolysin at an enzyme/p53 ratio of $1: 0.5($ lanes $2,5,8,11,14)$ or $1: 0.25(1$ anes $3,6,9,12,15)$ for $15 \mathrm{~min}$ at $37^{\circ} \mathrm{C}$. Reaction mixtures were electrophoresed on a $15 \%$ SDS-PAGE, and the gel was silver-stained. The arrowhead indicates the $35-\mathrm{kD}$ thermolysin protein, which silver-stains negatively because it is a metaloprotease. 


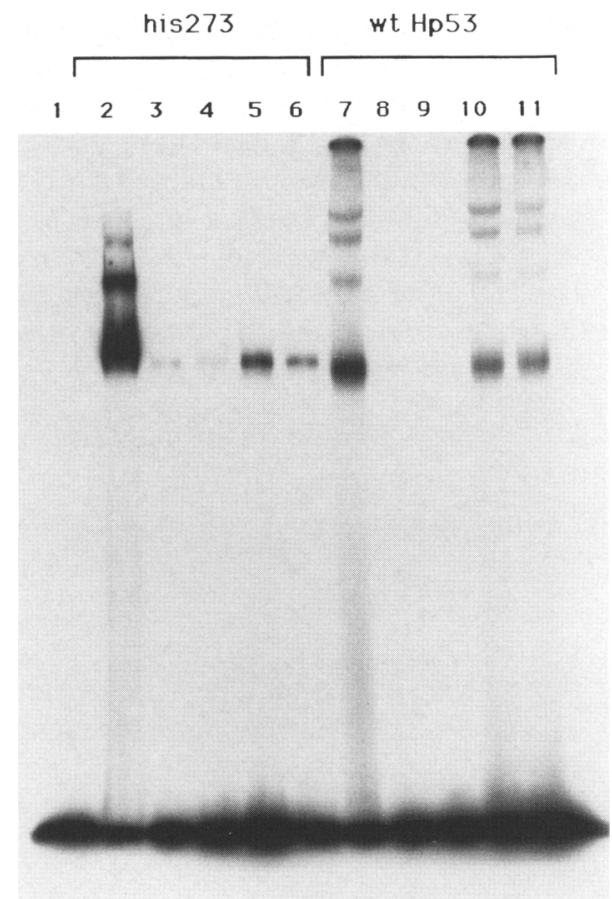

Figure 5. The tumor-derived mutant p53 (His-273) binds DNA at $20^{\circ} \mathrm{C}$. EMSA, comparing the DNA binding of wild-type and mutant His- 273 p53 proteins at $20^{\circ} \mathrm{C}$. Reaction mixtures contained 1.5 pmole of labeled MCK oligonucleotide and $1 \mu \mathrm{g}$ of either His-273 (lanes 2-6) or wild-type (lanes 7-11) p53 with no competitor DNA (lanes 2,7 ), or 20 (lanes 3,8 ) or 40 (lanes 4,9 ) pmoles of unlabeled RGC-W competitor, and 20 (lanes 5,10 ) or 40 (lanes 6,11) pmoles of unlabeled RGC-M competitor. Lane 1 contains 1.5 pmoles of labeled MCK oligonucleotide with no p53 protein.

was fairly effective at competing for binding to the labeled probe (Fig. 5, cf. lanes 5 and 6 with lanes 10 and 11). This result indicates that, although His-273 exhibits binding activity at $20^{\circ} \mathrm{C}$ as monitored by EMSA, the binding displayed is less specific than that demonstrated by wild-type $\mathrm{p} 53$.

We then determined whether the thermolysin-resistant fragment of His-273 mutant p53 was capable of binding to the ${ }^{32} \mathrm{P}$-labeled MCK oligonucleotide (Fig. 6). The mutant protein yielded a predominant $\sim 27-\mathrm{kD} \mathrm{mi-}$ grating fragment that was somewhat more resistant to proteolysis at $20^{\circ} \mathrm{C}$ than at $37^{\circ} \mathrm{C}$ (Fig. $6 \mathrm{~A}$ ). However, virtually no DNA binding by the mutant proteolytic digest was observed at either temperature (Fig. 6B, lanes 2-9). This was in marked contrast to the highly specific binding displayed consistently by the wild-type p53 thermolysin fragment (e.g., see Fig. 2). Thus, although similar protease-resistant fragments are generated from both His-273 mutant and wild-type p53, only the wild-type fragment binds to DNA. The binding displayed by the intact His-273 mutant protein at $20^{\circ} \mathrm{C}$ appears to be of a significantly different nature from wild-type p53 and may be controlled, to some extent, by sequences outside the central-core thermolysin-resistant fragment.

\section{Discussion}

The p53 tumor suppressor protein can function as a checkpoint factor (Hartwell 1992), causing cells that were exposed to DNA-damaging agents to arrest in $\mathrm{G}_{1}$ (Kastan et al. 1992; Hall et al. 1993). p53 presumably brings about this arrest, in part, by activating one or more genes that are part of a DNA damage-response

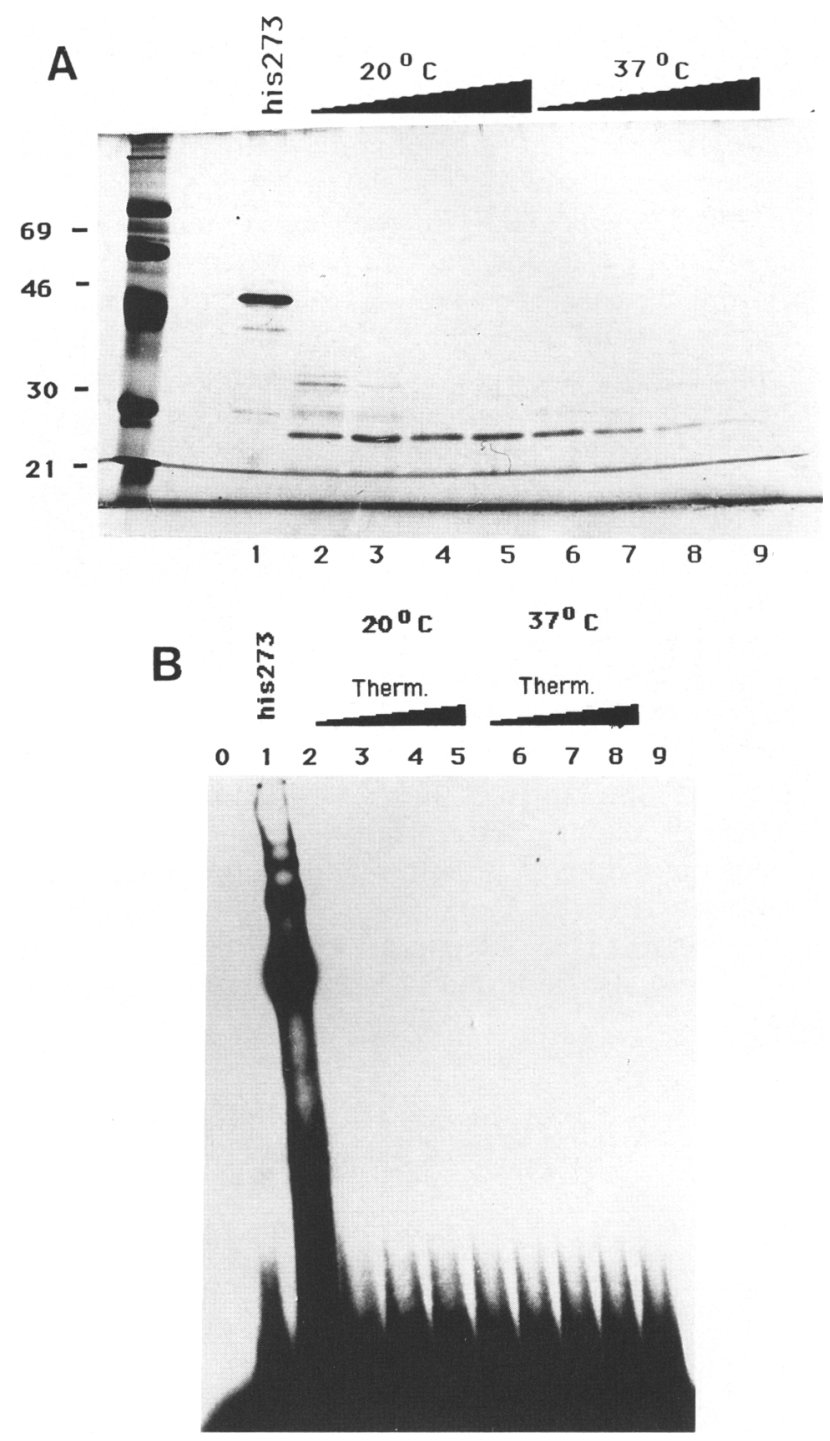

Figure 6. The thermolysin proteolytic fragment of mutant p53 (His-273) does not bind to DNA. Thermolysin digestion of $1 \mu \mathrm{g}$ of mutant His-273 p53 was carried out at $20^{\circ} \mathrm{C}$ and $37^{\circ} \mathrm{C}$ as indicated with protease/p53 weight ratios of 1:0.5 (lanes 2,6), 1:0.25 (lanes 3,7), 1:0.125 (lanes 4,8), and 1:0.06 (lanes 5,9) for 30 min. ${ }^{32} \mathrm{P}$-Labeled MCK oligonucleotide ( 1.5 pmole) was then added to each reaction mixture and incubated for $15 \mathrm{~min}$ more. Half of each reaction mixture was either electrophoresed on a $10 \%$ SDS-polyacrylamide gel and then silver stained to detect the appearance of the $\sim 27-\mathrm{kD}$ thermolysin-resistant fragment (A) or electrophoresed on a $4 \%$ acrylamide gel. The proportion of bound to free DNA was detected by autoradiography $(B)$. (Lane 1) Full-length untreated p53; (lane 0 ) no His-273 protein. 
pathway. The fact that tumor-derived mutant p53 proteins do not activate transcription (Farmer et al. 1992; Kern et al. 1992) nor induce $G_{1}$ arrest (Kastan et al. 1992) may contribute to the genetic instability that is a hallmark of the oncogenic state (Livingstone et al. 1992; Yin et al. 1992|. A key feature of transcriptional activation by p53 is the binding of the protein to DNA. Therefore, defining the region of p53 that is responsible for sequence-specific DNA binding will further our understanding of the normal function of $\mathrm{p} 53$. In this study we have isolated a thermolysin-resistant $\mathrm{p} 53$ fragment that exhibits strong sequence-specific DNA-binding activity in mobility shift assays. This fragment is the only polypeptide detected in the DNA-protein complex isolated from acrylamide gels and is not immunoreactive in Western blots with either the amino-terminal p53-specific antibody pAb 1801 or the carboxy-terminal-specific antibody pAb 421. Gas-phase sequencing has determined that the amino-terminal cleavage site is at position 91 , whereas treatment of intact $\mathrm{p} 53$ with cdc2 kinase and then cutting with thermolysin has demonstrated that the resistant fragment does not contain Ser-315. These data locate the site-specific DNA-binding domain to within the central conserved region of the protein (see Fig. 7). Our findings are consistent with the work of Pavletich et al. (this issue), showing that a bacterially expressed p53 polypeptide able to bind to DNA contains amino acid residues $102-292$. A feature that is common to all mutants tested is that they are defective in DNA binding. The fact that the vast majority of oncogenic mutations within $\mathrm{p} 53$ are located within the central portion of the protein fits extremely well with the location of the site-specific DNA-binding region that we have identified. Furthermore, our observation that SV40 T antigen, which was shown to bind to the central region of p53, abolishes specific DNA-binding by p53 provides further support for our conclusions.

Foord et al. (1991) proposed that the DNA-binding domain of $\mathrm{p} 53$ is contained within the carboxy-terminal 83 amino acids of the protein. This was based on their observation that truncated wild-type p53 lacking the carboxy-terminal 83 amino acids was unable to bind to DNA. However, in that study they neither used a defined p53-binding sequence nor demonstrated directly that the missing 83 amino acids were capable of specifically bind- ing to DNA; therefore, their original conclusion must be reinterpreted. It is now clear that the specific DNA-binding domain of p53 is not located within the extreme carboxyl terminus of the protein. Because p53 fragments containing sequences between residue 91 and 306 (this study), or Escherichia coli-expressed p53 polypeptide 102 - 292 (Pavletich et al., this issue), or a baculovirus-expressed p53 polypeptide containing residues $97-305$ (Jayaraman et al., unpubl.) all bind specifically to p53 DNAbinding sites, it is evident that the oligomerization domain of p53 that is located within the carboxyl terminus (Sturzbecher et al. 1992; Pavletich et al., this issue) is also not required for $\mathrm{p} 53$ sequence-specific DNA-binding activity. However, the question must then be posed as to why some forms of $\mathrm{p} 53$ that are truncated at, or deleted within, the carboxyl terminus oligomerization region show defective DNA-binding ability despite the fact that they retain the DNA-binding domain (Foord et al. 1991; Hupp et al. 1992; Shaulian et al. 1993; Jayaraman et al., unpubl.). One explanation for this apparent discrepancy is that in the absence of an intact carboxy-terminal region, the amino terminus may negatively regulate interactions by the central specific DNA-binding region. Preliminary experiments support this possibility (Jayaraman et al., unpubl.). This would be akin to the observation that the p53 carboxy-terminal-specific antibody pAb 421 activates p53 DNA binding (Funk et al. 1992; Hupp et al. 1992; Halazonetis et al. 1993; J. Bargonetti et al., unpubl.) and that there is a negative regulatory region within the extreme carboxy-terminal 30 amino acids with repression of DNA-binding that can be relieved by various treatments (Hupp et al. 1992). Thus, discrete sequences outside of the central region of p53 are capable of regulating the sequence-specific DNAbinding ability of the protein. Halazonetis et al. (1993) have suggested that the conformation of intact p53 changes when the protein binds to DNA. The ability to assume this conformational change may be regulated by sequences both within and outside of the central DNAbinding region.

The $\sim 27-\mathrm{kD}$ thermolysin-resistant DNA-binding p53 fragment contains four evolutionarily conserved regions that sustain a high occurrence of mutations in human cancers. The results from thermolysin digestion of the four mutant p53 proteins examined suggests that there

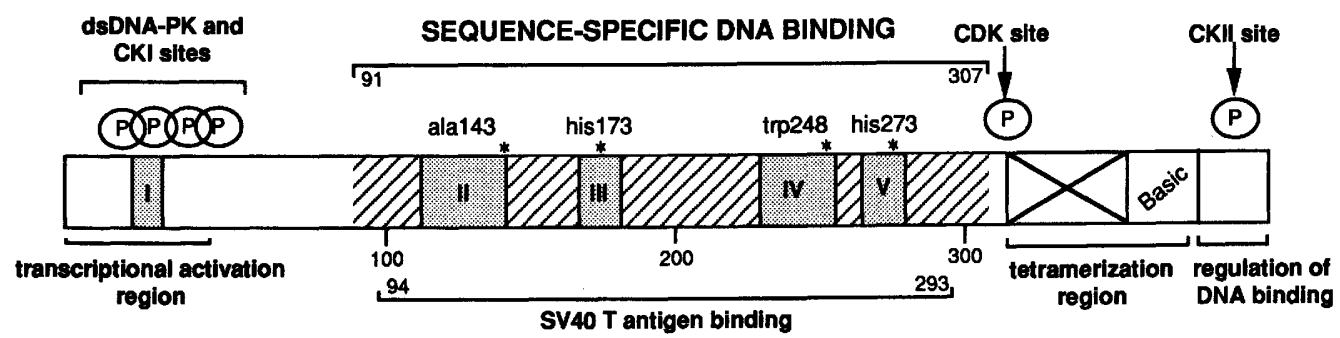

Figure 7. The central region of p53 binds to DNA. The lined area, spanning from 91 to 306, indicates the structural domain of p53 that binds sequence specifically to DNA. A detailed description of the diagram representing the structural domains of p53 is in Prives and Manfredi (1993). The five regions of p53 that are evolutionarily conserved are shown as stippled boxes; the asterisks ( ${ }^{*} \mid$ above them demark the substituted residues present in the oncogenic mutants described in this study. 
may be at least two classes of mutations that cause aberrant DNA binding. Two mutants, Trp- 248 and His273 , generated thermolysin digestion patterns similar to wild-type $\mathrm{p} 53$, suggesting that their structure is similar to wild type. If this is the case, then the inability of this class of mutants to bind to DNA may be attributable to changes in amino acids that make direct contact with the DNA. Interestingly Trp-248 and His-273 are transcriptionally active when fused to the GAL4 DNA-binding domain (Raycroft et al. 1991), which lends support to the above possibility. The two other mutants tested, Ala143 and His-175, were more highly susceptible to proteolysis, suggesting that they might be less tightly folded. Consistent with this observation is the fact these two mutants are defective in trans-activation when fused to the GAL4 DNA-binding domain (Raycroft et al. 1991). Furthermore, Ala-143 and His-175 were reported to bind to the Hsc70 heat shock protein, whereas wild-type p53 and His-273 do not (Hinds et al. 1990).

Other lines of evidence point to the importance of the central region for DNA-binding activity. Xenopus p53, which is only homologous to human p 53 in the central region, binds specifically to a human p53 consensus sequence (Y. Wang and C. Prives, unpubl.). Additionally, thermolysin treatment of either Xenopus or murine p53 protein yields a stable fragment that complexes with a strong DNA-binding site (Y. Wang, J. Bargonetti, and C. Prives, unpubl.). Hainaut and Milner (1993) showed that metal ions bind to the conserved cysteinyl residues in this central region, and this binding stabilizes the tertiary structure of wild-type p53. Pavletich et al. (this issue) have shown that metal binding by $\mathrm{p} 53$ is necessary for the central region to exhibit DNA-binding activity.

Although the central portion of p53 exhibits strong sequence-specific DNA-binding activity that is comparable to intact p53, it appears to have far less nonspecific DNA-binding activity than does the full-length protein. While full-length p53 was able to interact with a nonspecific oligonucleotide, the $\sim 27-\mathrm{kD}$ fragment was extremely defective, suggesting that amino acids outside the central domain are important for nonspecific DNAbinding activity. The fact that His- 273 mutant p53 was able to bind relatively nonspecifically to DNA when intact, but not when digested to yield the $\sim 27-\mathrm{kD}$ fragment, also suggests that there are two determinants for DNA binding by p53. Shaulian et al. (1992) have reported that the carboxy-terminal portion of p53, extending from residue 302 to 390 , is able to bind to DNA cellulose although it is unable to bind site specifically to DNA.

Although oncogenic mutant p53 proteins cannot bind site specifically to DNA, perhaps many maintain the ability to bind nonspecifically to DNA in vivo. If so, this property might contribute to the role of mutant $\mathrm{p} 53$ proteins in cell transformation (Dittmer et al. 1993). The nonspecific DNA binding of mutant proteins, coupled with their ability to maintain interactions with other regulatory proteins, might incur promiscuous regulation of many promoters, thereby trans-activating genes that under normal circumstances would be inactive. If this were the case, inactivating the nonspecific DNA-binding activity of mutant $\mathrm{p} 53$ protein might be a means to inactivate some of the transformation activity demonstrated by these mutants in human tumors.

\section{Materials and methods}

Purification of $p 53$ proteins

Recombinant baculoviruses expressing wild-type human $\mathrm{p} 53$ or mutant p53 proteins His-273, His-175, Ala-143 and Trp-248 were described previously (Bargonetti et. al. 1992, and references therein). Sf 21 insect cells $\left(2.5 \times 10^{7} / 150-\mathrm{mm}\right.$ dish) were infected with recombinant viruses and harvested at $48 \mathrm{hr}$ postinfection. Extracts of infected cells were prepared, and p53 proteins were purified from cell lysates by immunoaffinity procedures as described previously (Wang et. al. 1989). Protein A-Sepharose columns cross-linked with p53-specific monoclonal antibody pAb 421 (Harlow et. al. 1981) were used to purify p53 proteins. The proteins were eluted with pAb 421 epitope containing p53 peptide (KKGQSTSRHKK-OH) (Wade-Evans and Jenkins 1985/ and dialyzed into a buffer containing $10 \mathrm{mM}$ HEPES (pH 7.5), $5 \mathrm{~mm} \mathrm{NaCl}, 0.1 \mathrm{~mm}$ EDTA, $1 \mathrm{~mm} \mathrm{DTT}$, and $50 \%$ glycerol.

\section{Proteolytic digests of p53 proteins and DNA-binding assays}

Thermolysin digests of purified p53 proteins were carried out at either $37^{\circ} \mathrm{C}$ or $20^{\circ} \mathrm{C}$ in $50-\mu l$ reaction volumes containing $40 \mathrm{mM}$ creatine phosphate, $4 \mathrm{~mm}$ ATP, $7 \mathrm{~mm} \mathrm{MgCl}_{2}$, and $0.5 \mathrm{mM}$ DTT at enzyme/protein ratios as indicated. Over the course of these experiments the activity of the thermolysin preparations varied and the ratio for digestion was changed accordingly.

After protease treatment of p53, DNA was added as indicated. The synthetic double-stranded oligonucleotides used in this study (RGC-W, RGC-M, and MCK)-RGC-W; $5^{\prime}$-TCGAGTTGCCTGGACTTGCCTGGCCTTGCCTTTTC-3'; RGC-M; 5'-TCGAGTTTAATGGACTTTAATGGCCTTTAATTTTC-3'; MCK; 5'-TCGAGTGGCAAGCCTATGACATGGCCGGGGCCTGCCTCTCTCTGCCTCTGACCCTC-3'-which were described previously (Bargonetti et al. 1992), were labeled using the large fragment of DNA polymerase and $\left[\alpha^{-32} \mathrm{P}\right] \mathrm{dNTPs}$. Reaction mixtures $(50 \mu \mathrm{l})$ containing $40 \mathrm{mM}$ creatine phosphate, $4 \mathrm{~mm}$ ATP, $7 \mathrm{mM} \mathrm{MgCl}_{2}, 0.5 \mathrm{mM} \mathrm{DTT}$, and labeled oligonucleotide $\left(3 \times 10^{-7}\right.$ $M)$, as well as full-length or proteolytically-cleaved p53, were incubated at temperatures and for times as indicated. In some cases, unlabeled competitor poly [d(I-C)], RGC-W, or RGC-M was then added at indicated concentrations and the binding reaction was allowed to continue for the additional time as shown. The protein-DNA complexes were resolved by $4 \%$ native acrylamide gel electrophoresis in a buffer of $0.5 \times$ Tris-borate electrophoresis buffer (TBE). Each reaction mixture $(10 \mu l$ was electrophoresed on a $4 \%$ native gel for EMSA, and the remainder of each sample was analyzed by $10 \%$ or $15 \%$ SDSPAGE. The gels were either silverstained or electrotransferred to nitrocellulose and probed with p53-specific antibody pAb 240 (Gannon et al. 1990) or with a mixture of $\mathrm{p} 53$-specific antibodies [pAb 240, pAb 421, and pAb 1801 (Banks et al. 1986)].

\section{Elution of protein from native gels}

Elution of proteins from native acrylamide gels was essentially as described (Hager and Burgess 1980). Full-length purified p53 $(7 \mu \mathrm{g}$ ) or $\sim 25 \mu \mathrm{g}$ of thermolysin-digested p53 (at an enzyme to p53 ratio of $1: 1.75$ ) was bound to $3 \times 10^{-7}$ M labeled MCK for EMSA analysis. The thermolysin-treated protein /a combina- 
tion of four reaction mixtures loaded over four lanes) was electrophoresed on a $4 \%$ native gel, which was then exposed wet to $\mathrm{X}$-ray film overnight at $4^{\circ} \mathrm{C}$. The gel slices corresponding to the shifted complexes were excised, crushed, and soaked in elution buffer containing $0.1 \mathrm{mM}$ EDTA, $5 \mathrm{~mm}$ DTT, $0.20 \mathrm{M} \mathrm{NaCl}, 0.1 \%$ SDS, and $0.05 \mathrm{M}$ Tris $-\mathrm{HCl}(\mathrm{pH} 7.9)$ for $3 \mathrm{hr}$ at $25^{\circ} \mathrm{C}$. The crumbled gel was pelleted in a clinical centrifugation for $1 \mathrm{~min}$ at maximum speed, and the supernatant was then transferred into a siliconized $15-\mathrm{ml}$ Corex tube and precipitated with four volumes of ice cold acetone for $30 \mathrm{~min}$ in a dry ice ethanol bath. After centrifugation at $10,000 \mathrm{rpm}$ for $30 \mathrm{~min}$, protein-electrophoresis sample buffer was used to resuspend the pelleted material and the samples were separated on a $10 \%$ SDS-polyacrylamide gel.

\section{Amino-terminal sequence analysis of the p53 DNA-binding fragment}

Sequencing of the $\sim 27-\mathrm{kD}$ thermolysin-resistant p53 fragment amino terminus was as described (Matsudaira 1987). Purified wild-type human p53 (60 $\mu \mathrm{g})$ was digested with thermolysin at a ratio of $1: 0.5$ at $37^{\circ} \mathrm{C}$ for $30 \mathrm{~min}$. Unlabeled RGC-W oligonucleotide was added to the reaction mixture $(400 \mu l)$, and incubation was continued at room temperature for $30 \mathrm{~min}$. The reaction mixture was then concentrated in an Amicon concentrator spun at $5000 \mathrm{rpm}$ for $1 \mathrm{hr}$. The sample was then electrophoresed on a $10 \%$ SDS-polyacrylamide gel and electrotransfered to a ProBlott membrane (Applied Biosystems). The membrane was stained with Coomassie blue to visualize the proteolyzed p 53 product before amino-terminal sequence analysis by the Protein Chemistry Core Facility /Columbia University). Gas-phase sequencing was performed using an Applied Biosystems model $470 \mathrm{~A}$ protein sequencer/120A PTH analyzer for 10 cycles.

\section{Phosphorylation of p53}

Phosphorylation of p53 was carried out by incubation of p53 at $30^{\circ} \mathrm{C}$ for $30 \mathrm{~min}$ in buffer containing $50 \mathrm{mM}$ HEPES at $\mathrm{pH} 7.9,10$ $\mathrm{mM} \mathrm{MgCl} 2,1 \mathrm{~mm}$ DTT, $0.1 \mathrm{mM} \mathrm{ATP}$, and $25 \mu \mathrm{Ci}$ of $\left[\gamma^{32} \mathrm{P}\right] \mathrm{ATP}$ (New England Nuclear, $3000 \mathrm{Ci} / \mathrm{mmole}$ ), in the absence or presence of $0.8 \mathrm{ng}$ of cdc2 kinase (sp. act. $912 \mathrm{nmoles} / \mathrm{min}$ per $\mathrm{mg}$ ) purified from mitotic HeLa cells and characterized according to Marshak et al. (1991)

\section{Acknowledgments}

We thank N. Pavletich, K. Chambers, and C. Pabo for sharing information and providing helpful suggestions during the course of our work. We are grateful to Ella Freulich for expert technical assistance. This work was supported by National Institutes of Health grants (CA33620 and CA43460). J.B. was supported by a Damon Runyon-Walter Winchell Cancer Research Fund fellowship (DRG-1133).

The publication costs of this article were defrayed in part by payment of page charges. This article must therefore be hereby marked "advertisement" in accordance with 18 USC section 1734 solely to indicate this fact.

\section{References}

Banks, L., G. Matlashewski, and L. Crawford. 1986. Isolation of human-p53-specific monoclonal antibodies and their use in the studies of human p53 expression. Eur. I. Biochem. 159: $529-534$.
Bargonetti, J., P.N. Friedman, S.E. Kern, B. Vogelstein, and C. Prives. 1991. Wild-type but not mutant p53 immunopurified proteins bind to sequences adjacent to the SV40 origin of replication. Cell 65: 1083-1091.

Bargonetti, J., I. Reynisdottir, P.N. Friedman, and C. Prives. 1992. Site-specific binding of wild-type p53 to cellular DNA is inhibited by SV40 T antigen and mutant p53. Genes \& Dev. 6: 1886-1898.

Bischoff, J.R., P.N. Friedman, D.R. Marshak, C. Prives, and D. Beach. 1990. Human p53 is phosphorylated by p60-cdc2 and cyclinB-cdc2. Proc. Natl. Acad. Sci. 87: 4766-4770.

Cook, A. and J. Milner. 1990. Evidence for allosteric variants of wild-type p53, a tumour suppressor protein. Br. J. Cancer 61: $548-552$.

Dittmer, D., S. Pati, G. Zambetti, S. Chu, A.K. Teresky, M. Moore, C. Finlay, and A.J. Levine. 1993. Gain of function mutations in p53. Nature Gen. 4: 42-46.

El-Deiry, W.S., S.E. Kern, J.A. Pietenpol, K.W. Kinzler, and B. Vogelstein. 1992. Definition of a consensus binding site for p53. Nature Genet. 1: 45-49.

Farmer, G., J. Bargonetti, H. Zhu, P. Friedman, R. Prywes, and C. Prives. 1992. Wild-type p53 activates transcription in vitro. Nature 358: 83-86.

Fields, S. and S.K. Jang. 1990. Presence of a potent transcription activating sequence in the p53 protein. Science 249: 10461048.

Foord, O.S., P. Bhattacharya, Z. Reich, and V. Rotter. 1991. A DNA binding domain is contained in the carboxyl terminus of wild-type p53 protein. Nucleic Acids Res. 19: 5191-5198.

Funk, W.D., D.T. Pak, R.H. Karas, W.E. Wright, and J.W. Shay. 1992. A transcriptionally active DNA-binding site for human p53 protein complexes. Mol. Cell. Biol. 12: 2866-2871.

Gannon, J.V., R. Greaves, R. Iggo, and D.P. Lane. 1990. Activating mutations in p53 produce a common conformational effect. A monoclonal antibody specific for the mutant form. EMBO J. 9: 1595-1602.

Hager, D.A. and R.R. Burgess. 1980. Elution of proteins from sodium dodecyl sulfate-polyacrylamide gels, removal of sodium dodecyl sulfate, and renaturation of enzymatic activity: results with sigma subunit of Escherichia coli RNA polymerase, wheat germ DNA topoisomerase, and other enzymes. Anal. Biochem. 109: 76-86.

Hainaut, P. and J. Milner. 1993. A structural role for metal ions in the "wild-type" conformation of the tumor suppressor protein p53. Cancer Res. 53: 1739-1742.

Halazonetis, T.D., L.J. Davis, and A.N. Kandil. 1993. Wild-type p53 adopts a "mutant"-like conformation when bound to DNA. EMBO I. 12: 1021-1028.

Hall, P.A, P.H. McKee, H.P. Menage, R. Dover, and D. Lane. 1993. High levels of p53 protein in UV-irradiated normal human skin. Oncogene 8: 203-207.

Harlow, E., L.V. Crawford, D.C. Pim, and N.M. Williamson. 1981. Monoclonal antibodies specific for simian virus 40 tumor antigens. J. Virol. 39: 861-869.

Hartwell, L. 1992. Defects in a cell cycle checkpoint may be responsible for the genomic instability of cancer cells. Cell 71: 543-546.

Heinrikson, R.L. 1977. Applications of thermolysin in protein structural analysis. Methods Ezymol. 47: 175-189.

Herrman, C.P.E., S. Kraiss, and M. Montenarh. 1991. Association of casein kinase II with immunopurified p53. Oncogene 6: $877-884$

Hinds, P.W., C. Finlay, A.B. Frey, and A.J. Levine. 1987. Immunological evidence for the association of p53 with a heat shock protein, hsc70, in p53-plus-ras-transformed cell lines. Mol. Cell Biol.7: 2863-2869. 
Hinds, P.W., C. Finlay, R.S. Quartin, S.J. Baker, E.R. Fearon, B. Vogelstein, and A.J. Levine. 1990. Mutant p53 DNA clones from human colon carcinomas cooperate with ras in transforming primary rat cells: A comparison of the "hot spot" mutant phenotypes. Cell Growth Differ. 1: 571-580.

Hollstein, M., D. Sidrowsky, B. Vogelstein, and C.C. Harris. 1991. p53 mutations in human cancer. Science 253: 49-53.

Hupp, T.R., D.W. Meek, C.A. Midgley, and D.P. Lane. 1992. Regulation of the specific DNA binding function of p53. Cell 71: 875-886.

Jenkins, J.R., P. Chumakov, C. Addison, H.W. Sturzbecher, and A. Wade-Evans. 1988. Two distinct regions of the murine p53 primary amino acid sequence are implicated in stable complex formation with simian virus $40 \mathrm{~T}$ antigen. $J$. Virol. 62: 3903-3906.

Kastan, M.B., O. Onyekwere, D. Sidransky, B. Vogelstein, and R.W. Craig. 1991. Participation of p53 protein in the cellular response to DNA damage. Cancer Res. 51: 6304-6311.

Kastan, M.B., Q. Zhan, W.S. El-Deiry, F. Carrier, T. Jacks, W.V. Walsh, B.S. Plunkett, B. Vogelstein, and A.J. Fornace Jr. 1992. A mammalian cell cycle checkpoint pathway utilizing p53 and GADD45 is defective in ataxia-telangiectasia. Cell 71: $587-597$.

Kern, S.E., K.W. Kinzler, A. Bruskin, D. Jarosz, P.N. Friedman, C. Prives, and B. Vogelstein. 1991a. Identification of p53 as a sequence-specific DNA-binding protein. Science 252: 17081711.

Kern, S.E., K.W. Kinzler, S.J. Baker, J.M. Nigro, V. Rotter, A.J. Levine, P. Friedman, C. Prives, and B. Vogelstein. 1991b. Mutant p53 proteins bind DNA abnormally in vitro. Oncogene 6: 131-136.

Kern, S.E., J.A. Pietenpol, S. Thiagalingam, A. Seymour, K.W. Kinzler, and B. Vogelstein. 1992. Oncogenic forms of p53 inhibit p53-regulated gene expression. Science 256: 827830.

Lane, D.P. 1992. p53, guardian of the genome. Nature 358: $15-16$

Lane, D.P. and S. Benchimol. 1990. p53: Oncogene or anti-oncogene? Genes \& Dev. 4: 1-8.

Levine, A.J., J. Momand, and C.A. Finlay. 1991. The p53 tumour suppressor gene. Nature 351: 453-456.

Livingstone, L.R., A. White, J. Sprouse, E. Livanos, T. Jacks, and T.D. Tlsty. 1992. Altered cell cycle arrests and gene amplification potential accompany loss of wild-type p53. Cell 70: 923-935.

Marshak, D.R., M.T. Vanderberg, Y.S. Bae, and I.J. Yu. 1991. Characterization of synthetic peptide substrates for p34cdc protein kinase. J. Cell. Biochem. 45: 391-400.

Matsudaira, P. 1987. Sequence from picomole quantities of proteins electroblotted onto polyvinylidene difluoride membranes. J. Biol. Chem. 262: 10035-10038.

Meek, D.W., S. Simon, U. Kikkawa, and W. Eckhart. 1990. The p53 tumour suppressor protein is phosphorylated at serine 389 by casein kinase II. EMBO I. 9: 3253-3620.

Nigro, J.M, S.J. Baker, C. Presinger, J.M. Jessup, R. Hostetter, K. Cleary, S.H. Bigner, N. Davidson, S. Baylin, P. Devilee, T. Glover, F.S. Collins, A. Weston, R. Modali, C.C. Harris, and B. Vogelstein. 1989. Mutations in the p53 gene occur in diverse human tumor types. Nature 342: 705-708.

Prives, C. and J.J. Manfredi. 1993. The p53 tumor suppressor protein: Meeting review. Genes \& Dev. 7: 529-534.

Raycroft, L., H. Wu, and G. Lozano. 1990. Transcriptional activation by wild-type but not transforming mutants of the p53 anti-oncogene. Science 249: 1049-1051.

Raycroft, L., J.R. Schmidt, K. Yoas, M. Hao, and G. Lozano. 1991. Mol. Cell. Biol. 11: 6067-6074.
Ruppert, J.M. and B. Stillman. 1993. Analysis of a protein-binding domain of p53. Mol. Cell. Biol. 13: 3811-3820.

Scharer, E. and R. Iggo. 1992. Mammalian p53 can function as a transcription factor in yeast. Nucleic Acids Res. 20: 15391545.

Shaulian, E., A. Zauberman, D. Ginsberg, and M. Oren. 1992. Identification of a minimal transforming domain of p53: Negative dominance through abrogation of sequence-specific DNA-binding. Mol. Cell. Biol. 12: 5581-5592.

Shaulian, E., A. Zauberman, J. Milner, E.A. Davies, and M. Oren. 1993. Tight DNA-binding and oligomerization are dispensable for the ability of p53 to transactivate target genes and suppress transformation. EMBO J. 12: 2789-2797.

Soussi, T., C.C. deFromentel, and P. May. 1990. Structural aspects of the p53 protein in relation to gene evolution. Oncogene 5: 945-952.

Steinmeyer, K. and W. Deppert. 1988. DNA-binding properties of murine p53. Oncogene 3: 501-507.

Stephan, C.W. and D.P. Lane. 1992. Mutant conformation of p53: Precise epitope mapping using a filamentous phage library. J. Mol. Biol. 225: 577-583.

Sturzbecher, H.-W., R. Brian, C. Addison, K. Rudge, M. Remm, M. Gimaldi, E. Keenan, and J.R. Jenkins. 1992. A carboxyterminal a-helix plus basic region motif is the major structural determinant of p53 tetramerization. Oncogene 7: 1513-1523.

Tan, T.H., J. Wallis, and A.J. Levine. 1986. Identification of the p53 protein domain involved in formation of the simian virus 40 large $T$ antigen-p53 protein complex. $J$. Virol. 59: 574583.

Unger, T., M. Nau, S. Segal, and J. Minna. 1992. p53: A transdominant regulator of transcription whose function is ablated by mutations occurring in human cancer. $E M B O J$. 11: 1383-1390.

Vogelstein, B., and K.W. Kinzler. 1992. p53 function and dysfunction. Cell 70: 523-526.

Wade-Evans, A. and J.R. Jenkins. 1985. Precise epitope mapping of the murine transformation-associated protein, p53. EMBO I. 4: 699-706.

Wang, E.H., P.N. Friedman, and C. Prives. 1989. The murine p53 protein blocks the replication of SV40 DNA in vitro by inhibiting the initiation functions of SV40 large T antigen. Cell 57: 379-392.

Yin, Y., M.A. Tainsky, F.Z. Bishoff, L.C. Strong, and G.M. Wahl. 1992. Wild-type p53 restores cell cycle control and inhibits gene amplification in cells with mutant p53 alleles. Cell 70: $937-948$.

Zambetti, G.P., J. Bargonetti, K. Walker, C. Prives, and A.J. Levine. 1992. Wild-type p53 medicates positive regulation of gene expression through a specific DNA sequence element. Genes \& Dev. 6: 1143-1152. 


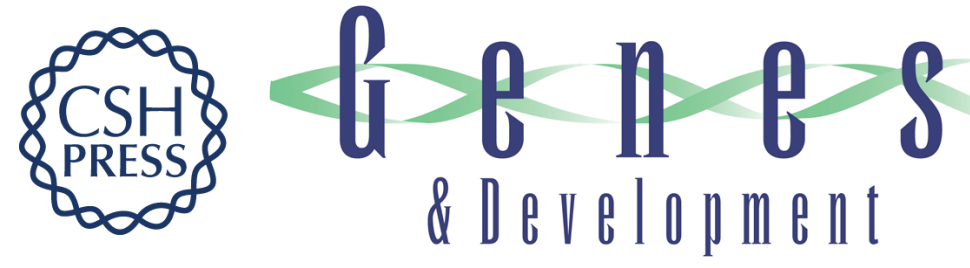

\section{A proteolytic fragment from the central region of p53 has marked sequence-specific DNA-binding activity when generated from wild-type but not from oncogenic mutant p53 protein.}

J Bargonetti, J J Manfredi, X Chen, et al.

Genes Dev. 1993, 7:

Access the most recent version at doi:10.1101/gad.7.12b.2565

References This article cites 56 articles, 22 of which can be accessed free at:

http://genesdev.cshlp.org/content/7/12b/2565.full.html\#ref-list-1

License

Email Alerting Service

Receive free email alerts when new articles cite this article - sign up in the box at the top right corner of the article or click here.

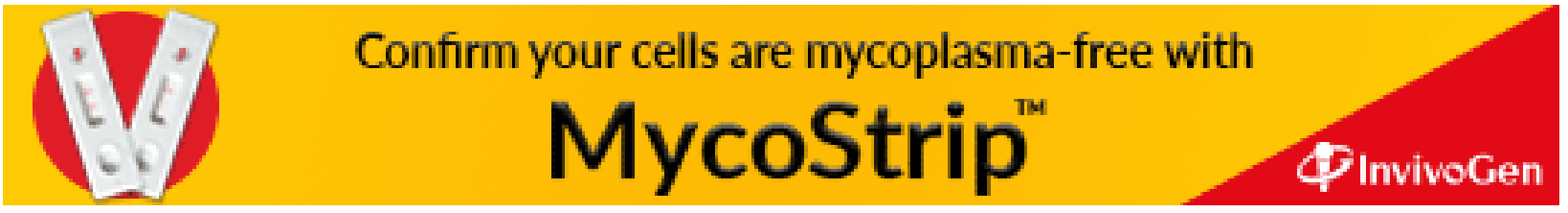

